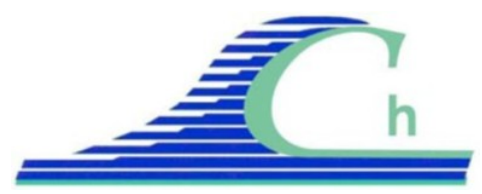

XII èmes Journées Nationales Génie Côtier - Génie Civil Cherbourg, 12-14 juin 2012

DOI:10.5150/jngcgc.2012.037-M ～(C) Editions Paralia CFL disponible en ligne - http://www.paralia.fr - available online

\title{
Récentes approches morpho-bathymétriques du plateau continental de Côte d'Ivoire (Golfe de Guinée)
}

\section{Sylvain MONDE ${ }^{1}$, Ama Valérie Irma WOGNIN ${ }^{1}$, Kouassi Laurent ADOPO ${ }^{1}$, Ted Edga WANGO ${ }^{1}$, Kouamé AKA ${ }^{1}$}

1. Département de Géosciences marines ; UFR-Sciences de la Terre et des Ressources Minières, Université de Cocody, 22 BP 582 Abidjan 22, Côte d’Ivoire.

atteson@gmail.com

\section{Résumé :}

La plate-forme continentale de Côte d’Ivoire présente deux importantes morphostructures. Ces importantes dépressions aux isobathes $100 \mathrm{~m}$ au large d'Abidjan et $70 \mathrm{~m}$ à Tabou n’étaient pas signalées par les cartes existantes. La direction structurale majeure des morpho structures suggère une origine tectonique lors de l'ouverture de l'Atlantique équatorial avec un contrôle par les courants de fond. D'autres originalités portent entre autre sur un trait de côte précis et des aspects géomorphologiques, l'extension et la typologie des pentes de la plate-forme continentale. Les progrès en océano-géologie ont permis de mettre en évidence ces particularités géomorphologiques. Le littoral ivoirien reste dynamique.

Mots-clés :

Morpho-bathymétrie - Trait de côte - Plateau continental - Côte d’Ivoire

\section{Communication non présentée}


Thème 2 - Dynamique sédimentaire 
XII ${ }^{\text {èmes }}$ Journées Nationales Génie Côtier - Génie Civil

Cherbourg, 12-14 juin 2012 
Thème 2 - Dynamique sédimentaire 
XII ${ }^{\text {èmes }}$ Journées Nationales Génie Côtier - Génie Civil

Cherbourg, 12-14 juin 2012 
Thème 2 - Dynamique sédimentaire 
XII ${ }^{\text {èmes }}$ Journées Nationales Génie Côtier - Génie Civil

Cherbourg, 12-14 juin 2012 
Thème 2 - Dynamique sédimentaire 